\title{
Advanced use of crop yield maps and histograms
}

\author{
Dr. Stanko Oparnica \\ Precise Agriculture Engineer at Alrawafed Serbia d.o.o, Serbia
}

Correspondence: Dr. Stanko Oparnica, Precise Agriculture Engineer at Alrawafed Serbia d.o.o, Serbia, Email Stanko.Oparnica@alrawafed-serbia.com

Received: May 10, 2018 | Published: May 21, 2018

Copyright@ 2018 Oparnica. This is an open access article distributed under the terms of the Creative Commons Attribution License, which permits unrestricted use, distribution, and reproduction in any medium, provided the original author and source are credited.

\begin{abstract}
Al Rawafed Serbia (ARS) company was established in 2015 and is working on 10.500ha, mainly field crops. Each of 25 main selfpropeled machines has Trimble navigation systems installed, with TMX 2050 monitor and modem, which provides data transfer. On combines, crop yield and moisture monitoring sensors were installed.

Trimble Ag desktop software enables an ability to create yield maps and histogram with different yield range and an ability to see the size of the yield zone. Using that data, it was found that the average yield masks real information about the yield across the field and regardless of cultivated crop and precipitation, the same zones show the same trend of yield differentials. Operator and machine issues are connected only to one crop year and they are not repeatable, but soil issues require deeper and studious research to determine if there is worth in investing in repairing the condition of the soil or just minimizing the amount of seed and fertilizer.
\end{abstract}

Keywords: precise agriculture, navigation, yield sensor, yield map

\section{Introduction}

Al Rawafed Serbia (ARS) company was established in 2015 and is working on 10.500 ha, mainly field crops (winter wheat, soy, corn, sunflower, barly and rape) and has small area under vegetable (tomato and potato). There is around 2000 ha under irrigation system and another 4500 ha of the systems is under construsction and should be finished in 2019 harvesting season.

ARS is using minimum tillage tehnology on their fields and is still using flat rate fertilizer and seed distribution. Each of 25 main selfpropeled machines has Trimble navigation systems installed, with TMX 2050 monitor under Android operating system and with modem, which provides data transfer (office/machines and vice versa). Additionaly, on combines, crop yield and moisture monitoring sensors were installed.

\section{Materials and methodology}

Main purpose of combine yield sensors is not to record an absolute yield with an accuracy of $1 \mathrm{~kg}$, rather to discover and map difference in yield. Sensors acquire data for every $30 \mathrm{~cm}$ on whole header working width and made points which contains data. Except information about dry yield, data cointains info about:
i. Combine speed
ii. Grain moisture
iii. Grain flow
iv. Wet yield

\section{v. Grain temperature}

vi. Working width etc.

All the data collected by the harvester during the work on one field, upon completion of work, are transferred with the modem to the Trimble cloud. Trimble Ag desktop software accesses data on cloud, downloads them to a computer and associates harvest information with previous operations for a given field (Figure 1).

The yield measurement system works on the principle of measuring the volume of mass that is transported to the combine grain bunker. Because of that, system does not distinguish grain from impurities. ARS has its own silos and grain cleaning system. Trimble Ag desktop software has an option of entering information about clean and dry yield under SRPS standard and creates additional layer - Reconciled yield. Information about clean and dry yield under SRPS standard for certain crop was used in all created maps (Figure 2).

Working with raw data is impractical, especially in fields with a large surface area, that contains an extremely large amount of data.

Trimble Ag desktop software enables an ability to create yield maps with different yield range and to see the size of the yield zone. ${ }^{1}$ This is important because it is used to standardize yields range for all fields under the same crop. For example, yield range for corn is $1 \mathrm{t} / \mathrm{ha}$, while for soybeans it is $0.5 \mathrm{t} / \mathrm{ha}$. For every yield map software also shows histogram, how many hectares contain certain yield range.

All created yield maps could be exported as SHP or KLM files, for further usage in other GIS software. 


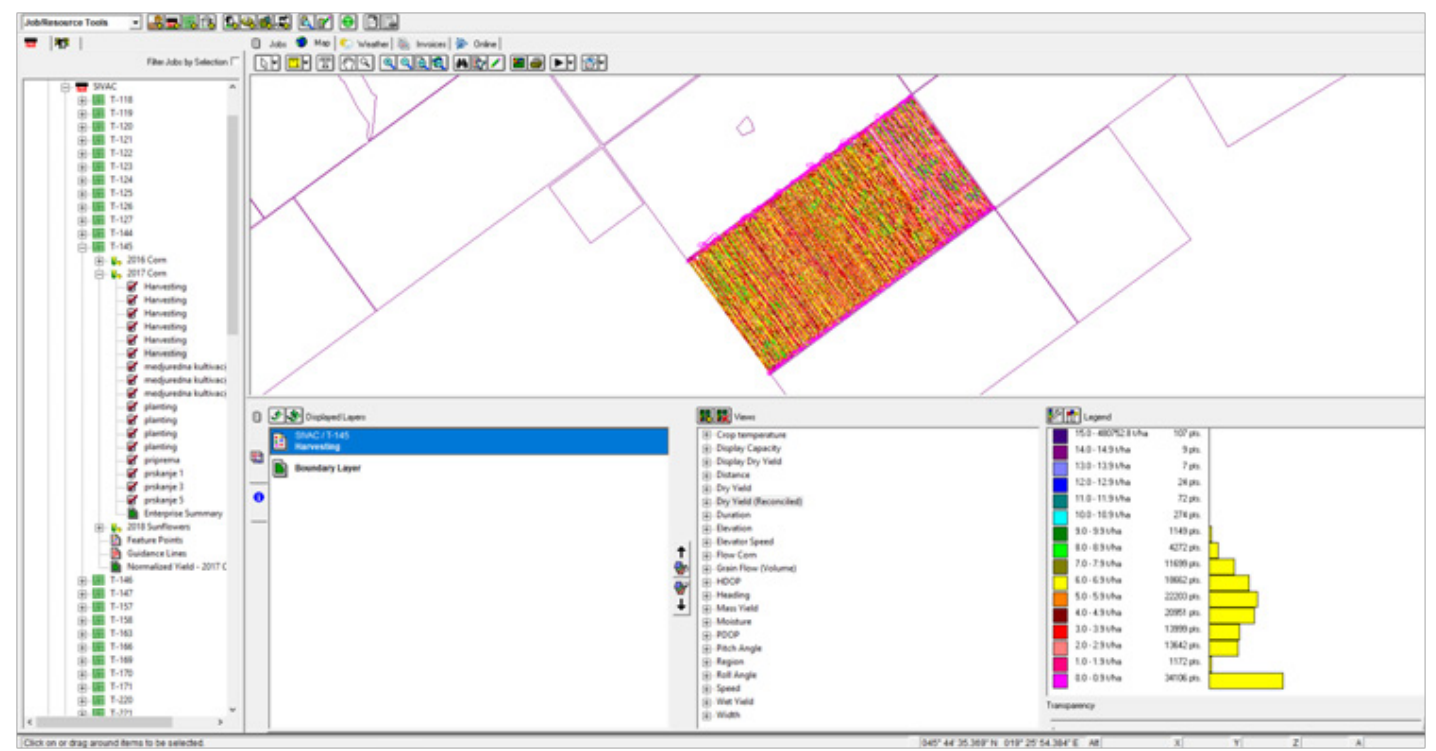

Figure I Row harvesting data for a crop I. Field name, harvest year and operations 2. List of acquired data 3. Map of raw data 4. Histogram of raw data.

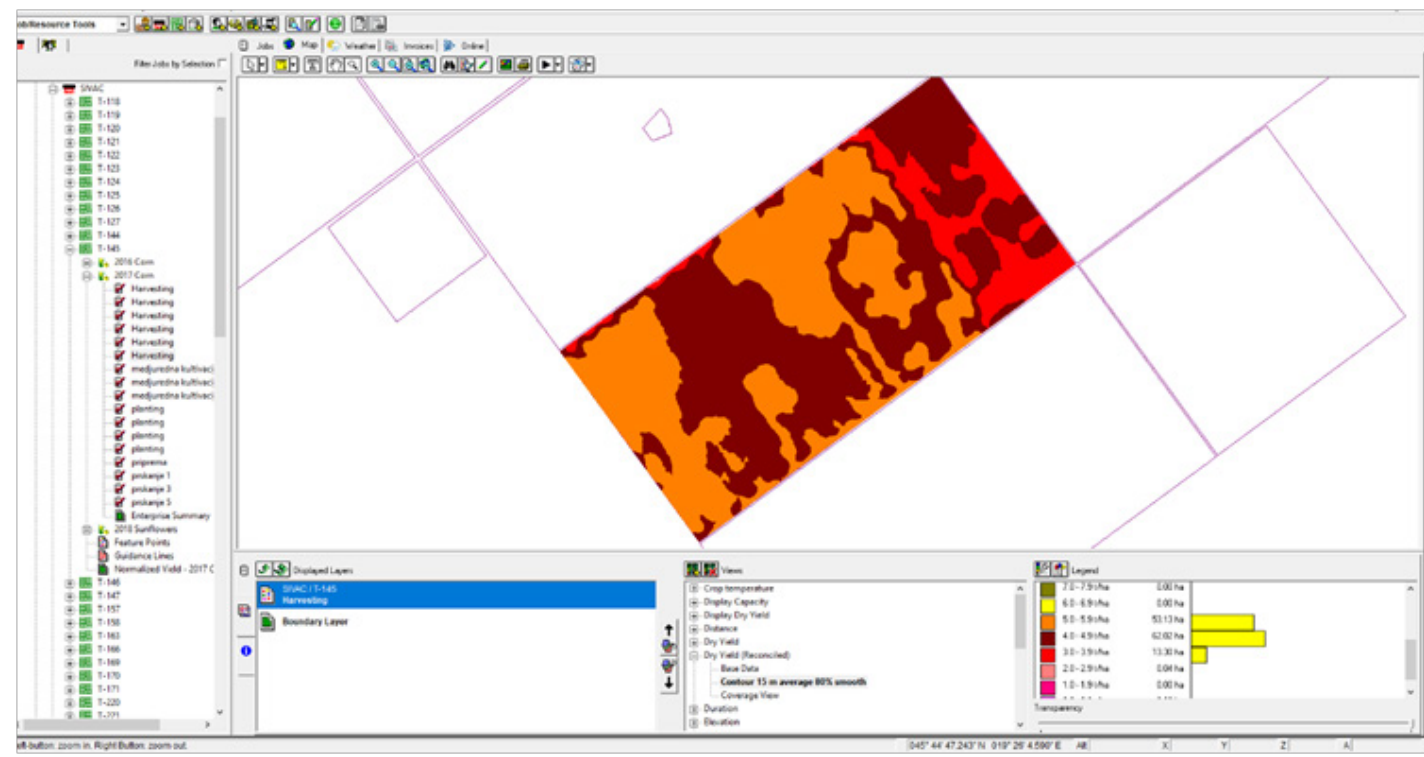

Figure 2 Reconciled yield map with yield histogram I. Dry yield map 2. Yield histogram.

\section{Results/discussion}

Trimble Ag desktop software is based on a single field information and doesn't allow yield analysis for more than one field. That is reason why next step is transferring data from all the yield histograms of one crop in the Excel table (Table 1).

For technical reasons, Table 1 contains only data from 4 fields and total areas. Blue marked cells show range where an average yield of that field is located. Using this table, it was found that the average yield masks real information about the yield across the field. On the field T-72, the average yield was $9,9 \mathrm{t} / \mathrm{ha}$. For Serbia that is a very good average yield, but an area of 7ha, with yield range from 0 to $1 \mathrm{t} /$ ha, was found on the same field. Summarizing the results of the 2017 wheat harvest year, it was found out that $60 \mathrm{ha}$ (or $4,42 \%$ of the entire surface area) had yield under $1 \mathrm{t} / \mathrm{h}$. If the average yield on that area is calculated and multiplied by the average price of wheat, the loss is around $50,000 €$.

Histogram (Figure 3) shows total wheat yield distribution by hectares. Area with yield under $5 \mathrm{t} / \mathrm{ha}$ is an area where we could make savings in seed and fertilizer. Because of flat rate distribution of seed and fertilizer area surface with yield of $1 \mathrm{t}$ and area surface with yield of $10 \mathrm{t}$ received the same amount of seed and fertilizer. Further research should determine the reasons of why these zones are less productive. It could be operators mistake during some operations, technical malfunction of machines (seed drill or sprayer) or an issue with the soil. Operator and machine issues are connected only for one 
crop year and they are not repeatable, but soil issues require deeper and studious research to determine if there is worth in investing in repairing the condition of the soil or just minimizing the amount of seed and fertilizer.

Figures 4 \& Figure 5 show yield maps for the same fields in the harvest years 2016 and 2017. In 2016 there was $1000 \mathrm{~mm} / \mathrm{m}^{2}$ of precipitation and in 2017 , only $380 \mathrm{~mm} / \mathrm{m}^{2}$. Regardless of cultivated crop and precipitation, the same zones show the same trend of yield differentials. This clearly shows that there is a serious soil issue in these zones.

Figure 6 \& Figure 7 show yield maps on the same field in different crop and year. In 2016 harvest year the crop grown on the field was soy and yield zones are oriented in planting direction. That is a clear sign that the yield difference is coused by operator or machine mistakes. When overlaping with spraying map was made, it was found out that the operator missed spraying of one row. Sprayer's working width is $36 \mathrm{~m}$, and that is about 5 combine passes.

In 2017 on the same field sunflower was grown. There is an obvious difference between the shape of the yield zones. It showes that mistakes coused by an operator in previous harvesting year are elimenated in the next harvesting year.

When a correlation was made between the amount of mineral fertilizer used and the resulting yield for different crops (Table 2), very negative results were obtained. This means that as much mineral fertilizer is "thrown" over the field, we get smaller yield.

Table I Yield ranges for fields of wheat

\begin{tabular}{|c|c|c|c|c|c|c|c|}
\hline yield/field & T-52 & $\mathrm{T}-54$ & $\ldots$ & T-7I & T-72 & Area [ha] & [\%] \\
\hline $12,1-13 t$ & & & & & & 1.02 & $0.07 \%$ \\
\hline $11,1-12 t$ & & & & 11.32 & 0.42 & 40.7 & $2.99 \%$ \\
\hline $10,|-| \mid t$ & & 4.89 & & 19.49 & 19.22 & 57.29 & $4.21 \%$ \\
\hline $9,1-10 t$ & 41.31 & 48.74 & & 9.81 & 16.61 & 159.8 & $11.74 \%$ \\
\hline $8,1-9 t$ & 69.12 & 38.95 & & & 7.2 & 237.46 & $17.45 \%$ \\
\hline $7,1-8 t$ & 69.29 & 3.9 & & 4.21 & & 291.01 & $21.38 \%$ \\
\hline $6,1-7 t$ & 21.84 & 0.77 & & & 9.16 & 241.03 & $17.71 \%$ \\
\hline $5,1-6 t$ & & & & & & 168.8 & $12.40 \%$ \\
\hline $4,1-5 t$ & & & & & & 66.49 & $4.89 \%$ \\
\hline $3, I-4 t$ & & & & & & 36.44 & $2.68 \%$ \\
\hline $2,1-3 t$ & & & & & & 0.61 & $0.04 \%$ \\
\hline$I, I-2 t$ & & & & & & 0.22 & $0.02 \%$ \\
\hline $0-I t$ & 14.1 & & $\ldots$ & 2.17 & 7.07 & 60.19 & $4.42 \%$ \\
\hline sowing time & I & I & $\ldots$ & I & I & 1361.06 & \\
\hline variety & MODERN & SOFRU & $\ldots$ & CELLULE & CELLULE & & \\
\hline precrop & sunflower & sunflower & $\ldots$ & wheat & wheat & & \\
\hline Yield $t / h a$ & 8.4 & 8.76 & $\ldots$ & 10.36 & 9.9 & & \\
\hline
\end{tabular}

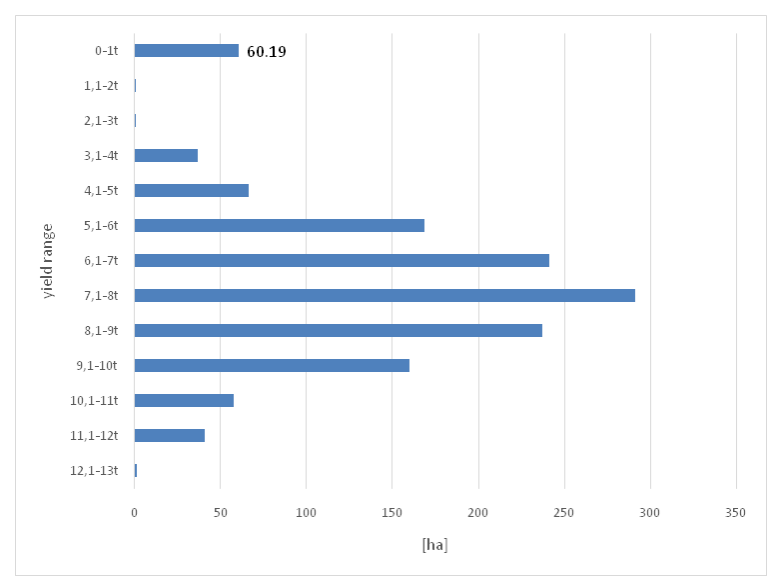

Figure 3 Summary wheat yield histogram.

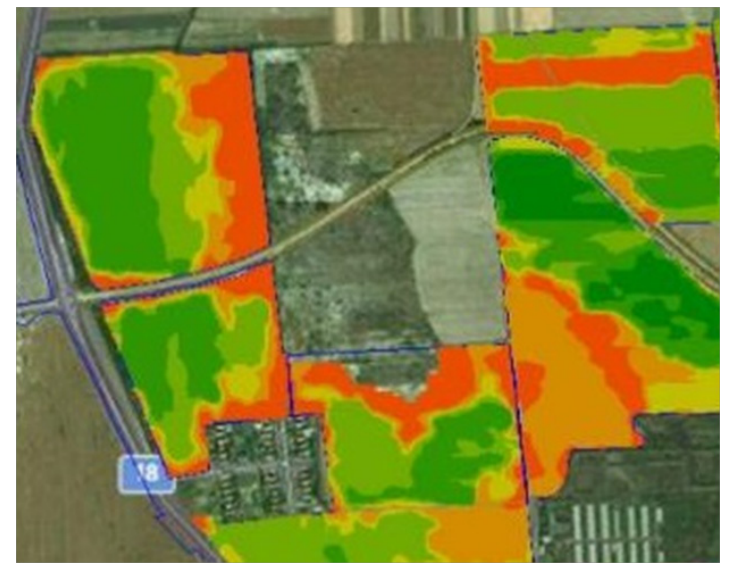

Figure 4 Yield map soy 2016, (red - low yield, green - high yield). 


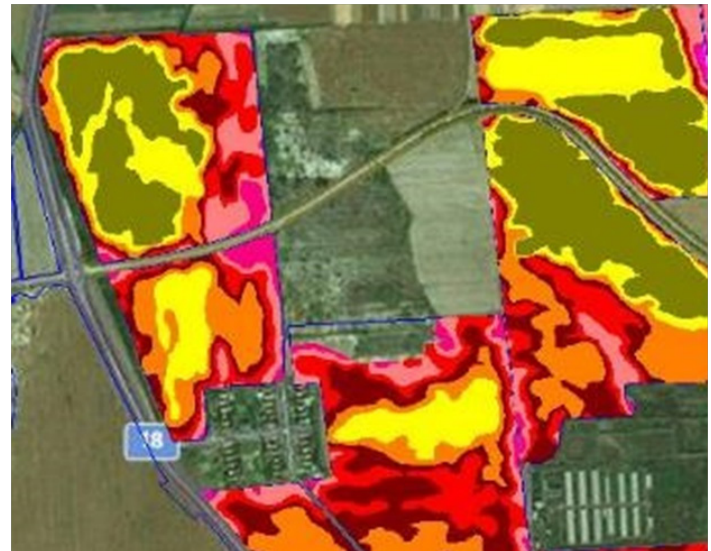

Figure 5 Yield map corn 2017 (red - low yield, green - high yield).

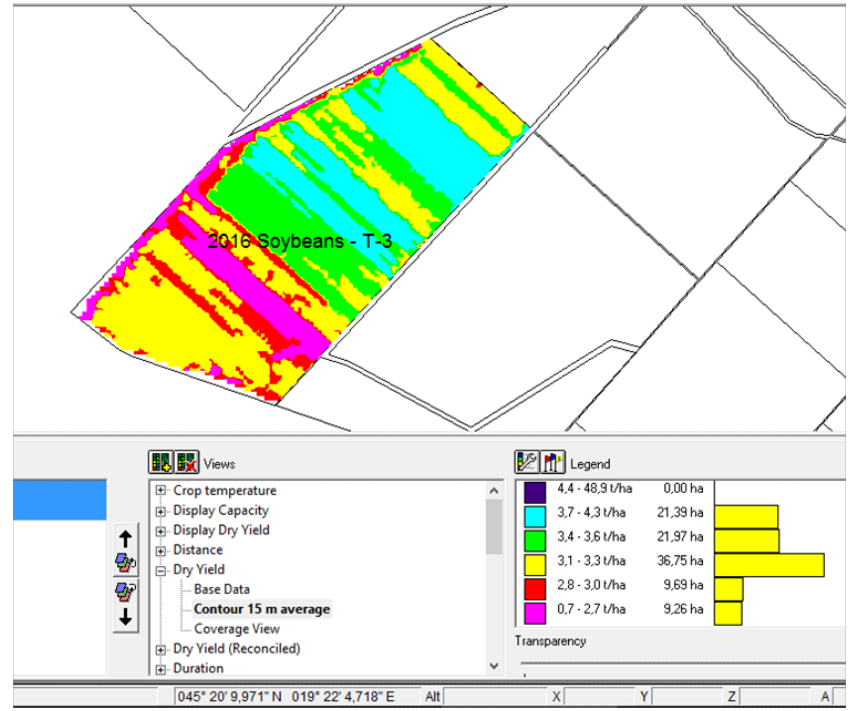

Figure 6 Zone with lower yield caused by human error marked by blue rectangle.

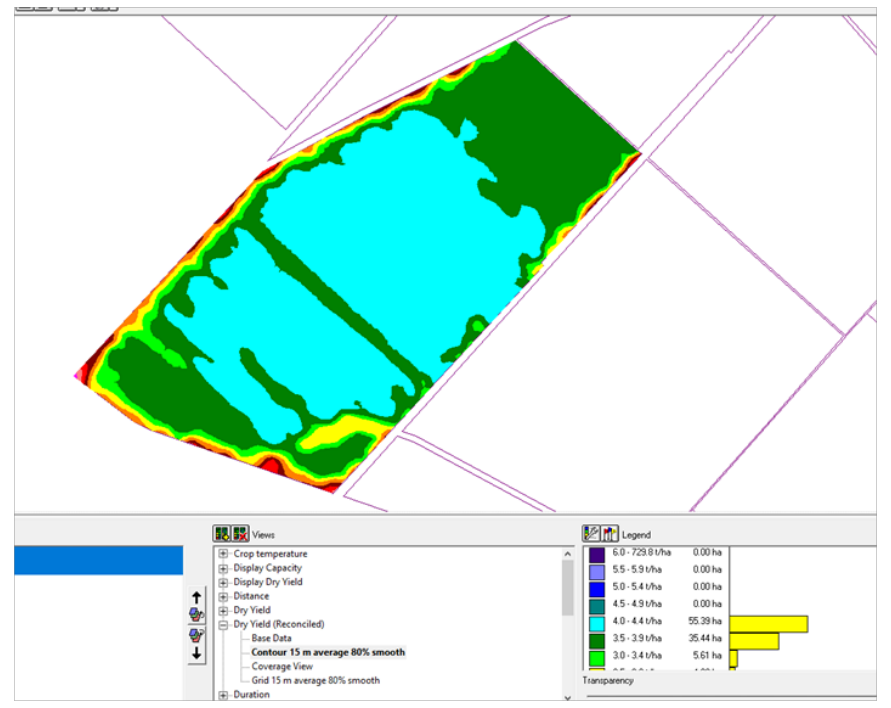

Figure 7 Yield map field T-3 sunflower 2017.
Based on the data in Table $1 \&$ Table 2, it was decided to calculate the difference between the given quantity of the fertilizer and the fertilizer that the plants use for each yield range. The result obtained exceeded all pessimistic expectations, ranging from a minimum of $10 \%$ to a maximum of $27 \%$. ARS spends more than 1million $€$ on mineral fertilizers each year. If the consumption of fertilizers can be reduced just by $10 \%$ using variable fertilizer distribution, large savings can be made and production costs could be significantly reduced.

Table 2 Correlation coefficient between used amount of fertilizer and realized yield for different crops

\begin{tabular}{llll}
\hline \multicolumn{4}{c}{ Crop } \\
\hline correlation & A & B & C \\
fertilizer/yield & $-0,51$ & $-0,39$ & $-0,03$ \\
\hline
\end{tabular}

\section{Conclusion}

i. ARS used yield maps only during 2 harvesting seasons, however the analysis of yield maps has provided results that we could not get before.

ii. Treatment of the field as if it has uniform characteristics over the entire surface is unsustainable.

iii. Even rate distribution of seeds and fertilizers is economically unfeasible, high costs with a decrease in yield. According calculation that was made, in 2017, ARS spent from $10 \%$ to $27 \%$ more fertilizers than was needed for the yield.

iv. Each field should be treated separately and divided into the management zones. Shape of zones can be obtained based on yield maps, but overlapping them with maps obtained by scanning the soil can get even more precise boundaries of the zone.

v. If there are significant problems with the land in the field, regardless of cultivated crop and precipitation by year, the same zones show the same trend of yield differentials.

\section{Acknowledgement}

None.

\section{Conflict of interest}

The author declares no conflict of interest.

\section{References}

1. Trimble Ag software user guide, Version 2017 Revision A. 2017.

2. Oparnica S, Sar I. Primena precizne poljoprivreda u proizvodnji soje: Deo 1- Efekat suše i đubrenja na prinos. Savr polj tehn. 2017;43(1):7-16.

3. Oparnica S, Sar I. Primena precizne poljoprivreda u proizvodnji soje: Deo 2-Mapiranje polja i pokazatelji prinosa. Savr polj tehn. 2017;43(2):75-84.

4. Dave Franzen, Francis Casey. Yield Mapping and Use of Yield Map Data. NDSU Publication; 2008.

5. Osvaldo Guedes Filho, Sidney Rosa Vieira, Marcio Koiti Chiba, et al Geostatistical analysis of crop yield maps in a long term no tillage system. Bragantia. 2010;69:9-18. 